\title{
LA DEMONSTRATION DE LA TECHNIQUE D'INTUBATION TRACHEALE
}

\author{
Marcer L. Boulanger, m.D., and Claude Lepage, M.D.•
}

LE MOIS DE JUILIET, comme à l'accoutumée, ramènera avec le soleil toute une génération de nouveaux résidents vierges de toute expérience en anesthésie et particulièrement incapables d'exécuter une intubation trachéale. Celle-ci est certainement une des techniques que l'aspirant anesthésiste doit maittriser le plus tôt possible pour sa propre tranquillité d'esprit, celle de ses moniteurs et pour la sécurité du patient.

Or malgré une connaissance parfaite de l'anatomie de la région et une familiarisation théorique avec la technique de l'intubation, celle-ci demeure difficile a apprendre et à démontrer: les laryngoscopes ne permettant qu'au seul exécutant l'accès visuel au larynx.

Nous avons tous connu, à titre de résidents, la frustration des intubations manquées que le patron devait effectuer après nos vaines tentatives et, comme patrons, nous ressentons encore souvent une certaine anxiété devant les "intubés de l'œesophage" et "les mutilés de l'épiglotte".

Pour rendre la démonstration de la technique plus efficace, nous avons monté un miroir laryngé, angulé à $45^{\circ}$, sur la lame droite d'un laryngoscope (Fig. 1). Dûment orienté, ce miroir permet à un observateur placé à l'endroit stratégique (Fig. 2) de suivre toutes les phases de lintubation, sans obstruer la vue de l'exécutant.

Nous avons pu, grâce à ce petit dispositif, faire exécuter des intubations dès la première tentative à des résidents relevant d'autres disciplines que l'anesthésie. Nous croyons que voilà la meilleure preuve de l'efficacité de cette innovation.

\section{SUMMARY}

It is important to the new resident to acquire facility in endotracheal intubation early in his training. In this way he achieves both his own tranquillity of mind and security for the patient. Although residents may know the regional anatomy and the theoretical principles of intubation, the practical application of the knowledge is quite a different matter. Demonstration of the technique is difficult, since the laryngoscope permits clear vision of the larynx to the operator alone. As residents all of us have experienced the frustrations of difficulties with intubation and all the complications it entails.

To permit the demonstration of intubation, a laryngeal mirror angulated at $45^{\circ}$ has been mounted on the straight blade of the laryngoscope (Fig. 1). This mirror allows the observer, when properly orientated (Fig. 2), to follow each step of the technique without obstructing the operator's view. We have seen residents on all services successfully perform an intubation at their very first attempt after such demonstration. This, we believe, proves the efficiency of the innovation.

-Service d'Anesthésie-Réanimation Notre-Dame, Hôpital Notre-Dame, Montréal. 


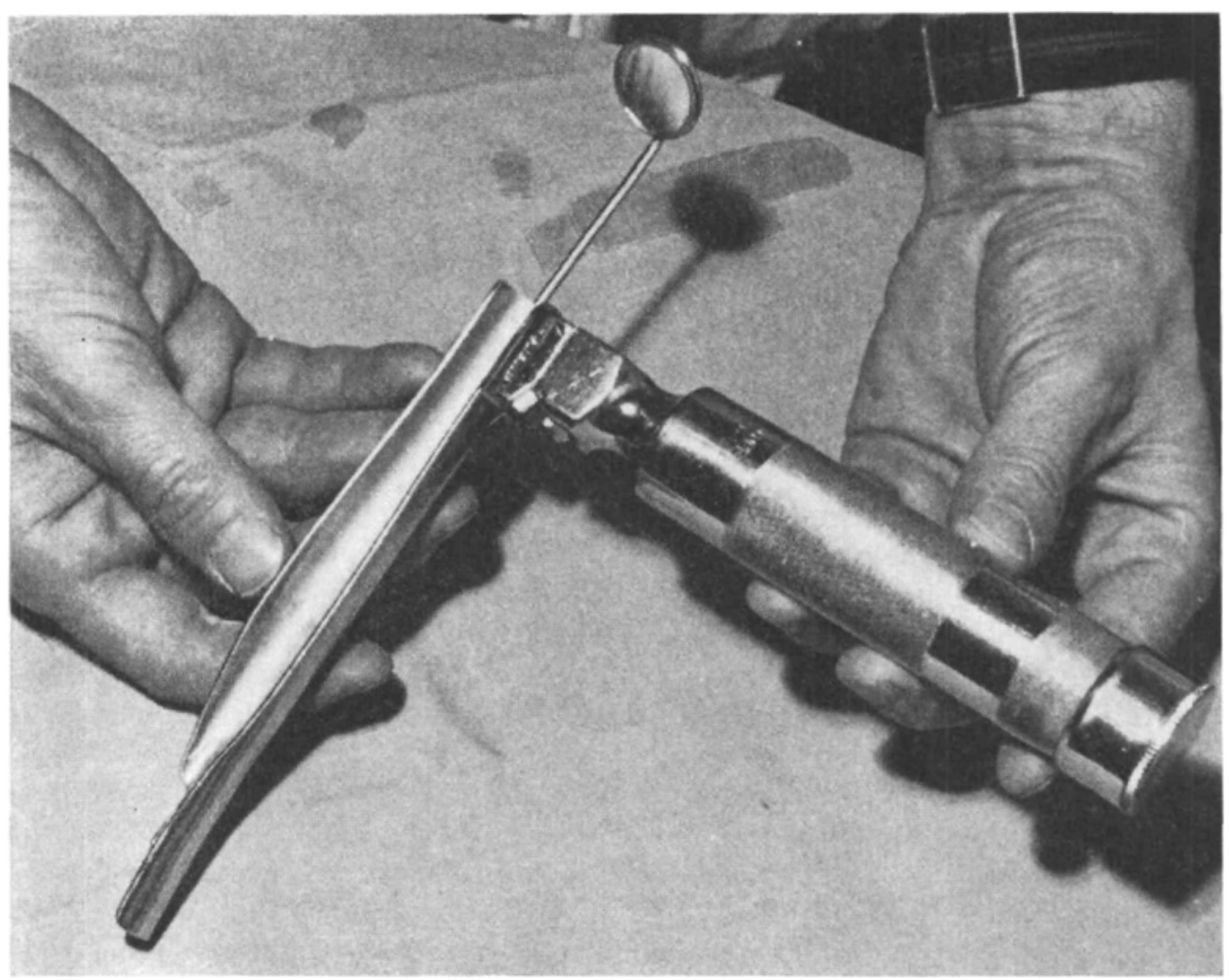

FIGURE 1

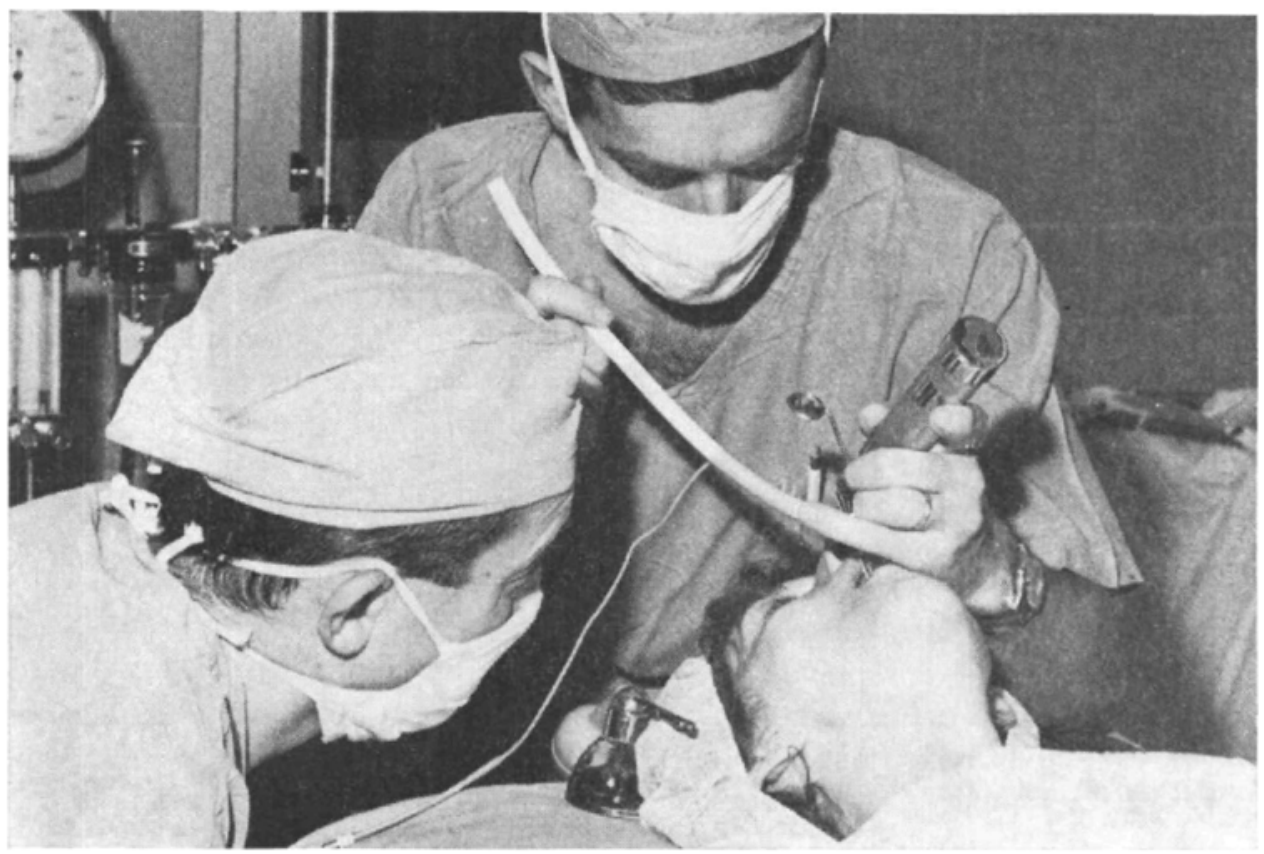

FIGURE 2 